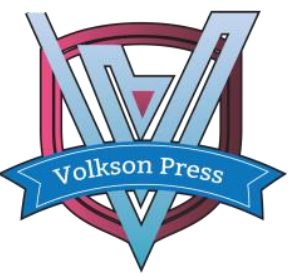

Contents List available at VOLKSON PRESS

Economics \& Management Innovations(EMI)

DOI : http://doi.org/10.26480/icemi.01.2017.61.62

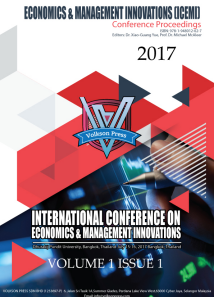

\title{
Brief Analysis on Cultivation of Innovative Talents in Agricultural E-commerce
}

\section{Jing Lin1, *, Simin-Pan2}

1School of Management, Wuhan Donghu University ,Wuhan,China

2School of Management, Wuhan Donghu University ,Wuhan,China

*624241059@qq.com

This is an open access article distributed under the Creative Commons Attribution License, which permits unrestricted use, distribution, and reproduction in any medium, provided the original work is properly cited.

\section{ARTICLE DETAILS}

\section{Article History:}

Received 02 october 2017

Accepted 06 october 2017

Available online 11 october 2017

\section{Keywords:}

agricultural

commerce.innovative

talents.training

\section{ABSTRACT}

On the purpose of promoting the cultivation of innovative talents who can design a suitable path combined with the current characteristics of Chinese agriculture,This document explains the present situation of innovative talents in agricultural electricity commerce field and demonstrates the reasons for the insufficiency.To meet the needs of sustainable development of agricultural electricity commerce talents and train qualified talents,government,enterprise organization (town)and university should cooperate closely to build talent flow platform,perfect training and developing system,and stimulate creative thinking etc.As for the innovation of this document,first,the hindering effect of traditional thought and crash course in reality;second,the solution to this issue in four aspects.

\section{Present situation of agricultural e-commerce innovative talents}

Hubei province has formulated "The three year action plan(2016-2018) for speeding up the development of rural electronic commerce of hubei province"In 2016. Which means the e-commerce enters into the agricultural field officially and will leading it's development.The future prospect is promising.Follow the policy guidance,more and more people apply their sights and implementations into the field of agricultural ecommerce,however, it did have a talent bottleneck in the process of vigorous development.

\subsection{Insufficient quantity of innovative talents in agricultural e- commerce}

According to the data of TaoBao University, the talent gap of e-commerce will be very large,about 4.45 million in the future three years[1].It's a difficult prospect,especially for agricultural e-commerce.In view of the start-up stage,agricultural e-commerce is faced with the shortage of talents.People will be used to simulate,not innovate,in the start-up stage,it's harmful to the development of any business.Nowadays,most agricultural e-commerce business are in the stage of copying the e-commerce pattern of other fields to agricultural field,rather than considering the reality.That's also the main reason for the short of innovative talents.

\subsection{Inadequate platforms for innovative talents in agricultural e-} commerce

The slogan of "Internet + agriculture" cried loudly, but it is limited in the actual operation of the platform. For many considerations such as market prospect, economic benefit, funding investment and so on, some areas still haven't supplied preferential policy for the agriculture e-commerce industry. In view of the character of agricultural products, people are also keep doubt in online purchase. Under the pressure and the limitation on platform, some innovative talents in agricultural e-commerce can do nothing with great ideas.

\subsection{Incomplete training system of innovative talents in} agricultural e-commerce

E-commerce education in our country emphasizes theory and neglects practice in those courses-opened school,the traditional teaching methods can be difficult to achieve the purpose of developing innovation thinking of talents.So it will be difficult to cultivate a large number of outstanding graduates to serve the society. Nowadays in China, there are less training institutions and social service agencies for agricultural ecommerce except school, course types are single and focused on agricultural technology rather than thinking extension, all these are unfavorable for the cultivation of innovative talents.

2. Reason analysis for the deficiency of innovative talents in agricultural e-commerce

\subsection{Wait-and-see attitude to emerging industry}

Inspired by the policy of "Technology Innovation","rejuvenate the country through science and technology",many young people have devoted to Internet field responding to the call of country.However, the fields gathered more in information technology services,cultural creativity and business services,but less in such as Agriculture and Farming. It is inevitable to hold a wait-and-see attitude for emerging industries: incompletely opened policy; limited fund of entrepreneurship and development; platform lack;consumer's distrust to online purchase channels, etc. All of these have hindered the development of agricultural e-commerce, and lead to a lot of ideas be deterred or entrepreneurial failure.

\subsection{Influence of traditional ideology}

Under the influence of traditional thought,people now still discriminate against agricultural.Rural labor poured into city hoping for removing farmers label through the urbanization,while jobs about developing agriculture or rural are always rejected by the higher educated.Because of this, the development of agriculture in our country can only rely mainly on labors with low level of education,social development capability and innovation thinking relatively for a long time.It lacks effective connection between agriculture and talents.The existence of a vicious cycle hinders the development of agricultural innovation.

\subsection{Deficiency in effective training courses design}

Trainees of agricultural e-commerce can be divided into two kinds, one is with e-commerce knowledge but lack of agriculture,the other is lacks of ecommerce knowledge but familiar with agriculture.A general problem in existing training is pursuing a crash.For example,they teach farmers basic operation courses such as how to copy e-commerce transaction pattern from other field in a short time.Most of the social training institutions prefer to increase the training scale rather than take risks to carry out new training program like e-commerce[2].What crash courses teach is just imitation but 
not how to select the appropriate channels and means for their own development according to its own characteristics, what we called "innovative thinking".

\section{Countermeasure and suggestion}

\subsection{To strengthen the supporting force to provide convenience for} agricultural e-commerce

It's essential for government departments to provide policy,financial and channel supports for the cultivation of innovative talents in agricultural ecommerce field.Based on government's support,we can cultivate interdisciplinary talents with e-commerce theory and practical ability,and also can provide a platform for "Internet + agriculture" entrepreneurs.The positive role of government can promote good practice of university and corporation training plan,as well as provide guarantee to training and development of innovative talents.

\subsection{To establish effective channels and to encourage two-way flow}

One mainly reason of shortage of agriculture e-commerce talents is lack of flow, talents are limited in their respective fields.To break the confine situation, conditional town (street) can use idle workshop to set up ebusiness incubator, to provide low-cost e-commerce public services for

entrepreneurial farmers;Social organizations can establish an effective channel to attract aspiring young to rural and stay here.Which can form abundant talents base to sever in rural areas better.

\subsection{To build course system with the requirement of society and to carry out cooperation between higher vocational colleges actively}

To cultivate innovative talents who can quickly adapt to the social development and meet the social demands,it's essential to innovate teaching mode and break the old which baffled the cultivation of innovative abilities[3].First of all,university should establish professional agricultural e-commerce team composed by academic leaders,enterprise experts and senior technicians.Enterprise and university cooperate with each other to train and teach.Secondly,to organize students to participate in skills competition actively to build the platform for enterprises and students.Thirdly,to encourage enterprises to enter competition by business capital or opportunity of internship which can make e-commerce courses more closer to social development needs and promote the development of reserve talents in creativity.Finally, universities should offer training and learning opportunities to enterprise on-the-job personnel or rural public servants, and give development opportunity to potential talents who are interested in e-commerce but lack of system knowledge.

\subsection{To set up perfect training and development system step by step}

The effect of crash course is transient,We must establish a perfect training and development system to achieve long-term development.The first step is deeper analysis of the requirements ,including policy,personnel, concept,technical and psychological etc.Among these,psychological analysis is the easiest part to be neglected.Psychologists have argued that people with some certain personality characteristics and traits are more easier to be inspired creative thinking.So it helps to develop potential by psychological traits analysis of innovative talents.Courses are designed based on it,such as Policy interpretation courses according to policy analysis to wide sight and thought;Psychological diathesis and traits courses according to psychological traits analysis;and so on.

The establishment of training system can't be achieved overnight,constantly improving and perfecting are grounded on assessment.Relying on it and reward measures,it can not only perfect the training system and improve the quality of training,but also inspire more talents with good ideas.

\section{Conclusion}

Electronic commerce is the effective bridge connecting agricultural and talents,which is propitious to introduce the ideas to agriculture and expand the industrial chain of agriculture to the whole world.For the long term goals,we must cultivate innovative talents who can design a suitable development path combining with characteristics of Chinese agriculture;must encourage technicians to the countryside and farmers to do pioneering work;must build interrelated training system actively and gradually implemented.Only in this way can we adapt to the rapid development and huge potential trend of the Internet,and convey innovative talents steadily.

\section{Acknowledgment}

This work was supported by the grants from Hubei Provincial Collaborative Innovation Center of Agricultural E-Commerce(under Construction)(Wuhan Donghu university research [2015] No. 11 Document).

\section{References}

[1] Yichen Wang:Exploration of social training system of e-commerce highskilled talents.Modern Economic Information Vol.24(2015).

[2] Wanmin Ma:Discussion on the questions and answers of exploitation of e-commerce professionals.Economist Vol.11(2002).

[3] Xiaonian He,Fenghua Duan.Discussion of Mobile e-commerce innovative talents training ways.Education teaching BBS Vol.12(2015).

[4] Qiao Zhao.Exploration of innovative personnel training mode of mobile e-commerce in professional building.Modern Economic Information Vol.27(2016).

[5] Yongxiu He,Jiang Zhu:Research on the training mode of innovative talents in E-commerce Specialty.Journal of North China Electric Power University(Social Sciences) Vol.5(2010).

[6] Jinlian Mao: Research on the current situation and development of ecommerce talents. E-business Vol.3(2013).

[7] Ping Li:The construction of innovative practical talents training system of E-commerce Specialty.Research and exploration in laboratoryVol.3(2014).

[8] Lihua Wei:The construction and practice of Yiwu 300 thousand ecommerce personnel training curriculum system.Adult education Vol.2(2015) 